\title{
炭素鋼焼なまし材の寸法効果についで
}

$$
\text { 大内田 久** 岩崎勤** 長尾真 } \text { 人** }^{* *}
$$

\section{Size Effect on Fatigue of Annealed Carbon Steel}

by

\author{
Hisashi OHuchida, Tsutomu Iwasaki and Masato NAGaO \\ (Hitachi Research Laboratory, Hitachi Ltd., Hitachi)
}

The X-ray back diffraction method was used for the nondestructive direct detection of fatigue damage in the machine parts of larger size. The size effect on fatigue of annealed carbon steel was also studied.

The results obtained in this experiment are as follows.

(1) Whether the applied cyclic stress is larger or smaller than the fatigue limit of the specimen can be estimated by the back diffraction pattern in the case of unnotched test specimens, irrespective of the specimen sizes. On the other hand, the fatigue limit estimated from the X-ray pattern in the case of the specimen with a shoulder fillet is a little lower than the true fatigue limit. It is considered to be due to the stress gradient in the fillet.

(2) The changes in residual stress and half-value breadth of diffraction line width during the fatigue process in the case of unnotched specimens depend on the specimen size even under the same applied stress. This result shows also that the size effect on fatigue strength must vary according to the strength near the specimen surface, which will be emphasized by stress gradient.

It can also be concluded from the results obtained that the X-ray diffraction method is available for the detection of fatigue damage in the specimens of different size.

(Received Aug. 16, 1968)

\section{1 緒言}

鋼材の疲労強度に及ぼす寸法効果の研究は, 従来多 くの研究者によって行なわれてきて拈り, また，これ らの研究結果についての総合的解説もなされている.

しかし, この寸法効果の研究は多大の費用と時間を 要し，その上種々の困難を伴うため，今日に打いても な打資料が不足している。 そこで, 多くの場合, 大型 機械部品を設計する際も, 疲労強度の見積りは, 小型 試験片の疲労限度加㐫る仮定をして求められている。 このような事情からも疲労の検出を大型部材に掠いて 行ならことが必要とされるゆえんがある。

大型試験片に扔いて（たとえば $100^{\phi}$ ) 試験片の受 ける被害の様子を詳細化調べ，との㙨構を追求した例 はみられない。一方，X線に上る疲労の検出に関する 今日までの研究は, 研究室的実験であり, 疲労の機構 の検討である。そこで，X線による疲労の検出を実物

* 本報を「X線による機械部品の疲労の検出（第 1 報)」(X-Ray Investigation on the Detection of Fatigue Damage in Machine Parts, I) とする.

原稿受理 昭和 43 年 8 月 16 日

**（侏）日立製作所日立研究所 日立市幸町

*** 正会員 (株) 日立製作所日立研究所日立市幸町
大型機珹部品汇応用しょらとする場合，はたして小型 試験片にて得られた従来の検出法が，大型寸法部材に いかにあてはまるかを検討する必要があるう。

すなわち，X線汇よる観察は試験片のごく表面に限 られるが，大型寸法部材に执いても疲労被害が検出で きらるものか否かを検討することとした。

そのために，機械部品の代表的なものとして車軸を 取り上げ，その実物寸法にかなり近い大型試験片（平 滑材 $100^{\phi}$, 段付材 $80^{\phi}$ ) を用いてX線的疲労の検出 （半洒幅变化拉よび残留応力变化）に及ぼ寸寸法の影 響を検討した。ささらに，形状の影響（平滑材抢よび段 付材）を検討した.

\section{2 研究の方法}

\section{$2 \cdot 1$ 試 験 片}

試験片粗材は軟鋼 SF $55\left(180^{\phi}\right)$ であり, $880^{\circ} \mathrm{C}$ に て13時間空中焼ならしをしている。粗材の材質ならび 飞機戌的性質を Table I 飞示す。試験片形状は Fig. 1 (a)〜(e)飞示すように, 平滑試験片と段付試験片であ る. 図中の寸法を Table II に示す。試験片名称は Table II に示すように平滑試験片にては, 大型, 中 型, 小型の 3 種類, 段付試鈳片にては, 大型, 中型の 
Table I. Chemical composition and mechanical properties.

\begin{tabular}{|c|c|c|c|c|c|}
\hline \multirow{2}{*}{$\begin{array}{l}\text { Chemical composition } \\
\text { (\%) }\end{array}$} & $\mathrm{C}$ & $\mathrm{Si}$ & $\mathrm{Mn}$ & $\mathrm{P}$ & $\mathrm{S}$ \\
\hline & 033 & 0.30 & 058 & 0.013 & 0010 \\
\hline \multirow{2}{*}{ Mechanıcal properties } & $\begin{array}{c}\text { Yelding point } \\
\left(\mathrm{kg} / \mathrm{mm}^{2}\right)\end{array}$ & $\begin{array}{c}\text { Tensile strength } \\
\left(\mathrm{kg} / \mathrm{mm}^{2}\right)\end{array}$ & Elongation $(\%)$ & $\begin{array}{c}\text { Contraction of area } \\
(\%)\end{array}$ & $\begin{array}{c}\text { Vicker's hardness } \\
H_{V}\end{array}$ \\
\hline & 409 & 643 & 29.2 & 51.0 & 173 \\
\hline
\end{tabular}

Table II. Specimen size and heat treatment.

\begin{tabular}{|c|c|c|c|c|}
\hline Specimen & Fatigue machine & Specimen geometry & Specimen size $(\mathrm{mm})$ & Condition of heat treatment after machine shaping \\
\hline Small & $\begin{array}{l}\text { Cantilever rotating } \\
\text { bending }\end{array}$ & Smooth & $d=8$ & $650^{\circ} \mathrm{C}, 1 \mathrm{hr}$ annealed in a vacuum furnace \\
\hline \multirow[t]{2}{*}{ Middle } & \multirow{2}{*}{$\begin{array}{l}\text { Cantilever rotating } \\
\text { bending }\end{array}$} & Smooth & $d=20$ & \multirow[t]{2}{*}{$650^{\circ} \mathrm{C}, 2 \mathrm{hr}$ annealed in a vacuum furnace } \\
\hline & & $\begin{array}{l}\text { With a shoulder } \\
\text { fillet }\end{array}$ & $\begin{aligned} d & =1562 \\
D & =16.40 \\
r & =0.50\end{aligned}$ & \\
\hline \multirow[t]{2}{*}{ Large } & \multirow[t]{2}{*}{ Rotating bending } & Smooth & $d=100$ & \multirow[t]{2}{*}{$650^{\circ} \mathrm{C}, 3 \mathrm{hr}$ annealed in an Ar-gass } \\
\hline & & $\begin{array}{l}\text { With a shoulder } \\
\text { fillet }\end{array}$ & $\begin{aligned} d & =80 \\
D & =84 \\
r & =2.56\end{aligned}$ & \\
\hline
\end{tabular}

(a)

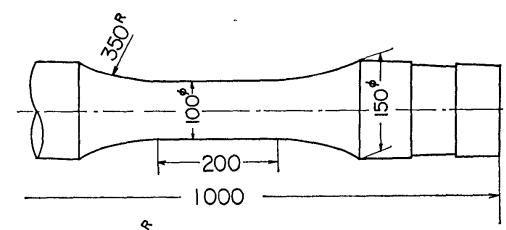

(b)

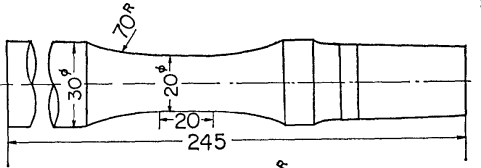

(c)

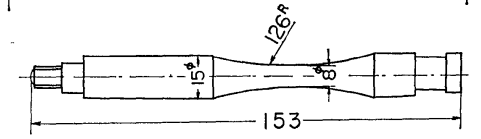

(d)

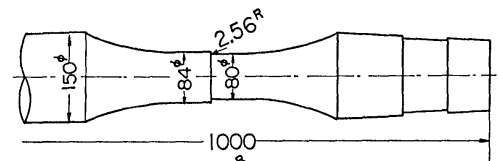

(e)

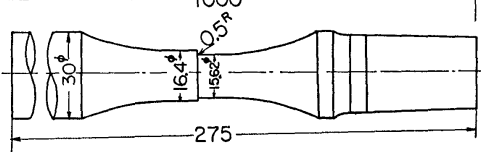

(a) Unnotched specimen of large size

(b) Unnotched specimen of middle size $\left(\alpha_{k} \leq 1\right.$ 002)

(c) Unnotched specimen of smalle size $\left(\alpha_{k} \leq 1002\right)$

(d) Specimen of large size with a shoulder fillet $\left(\alpha_{k}=2\right)$

(e) Specimen of middle size with a shoulder fillet $\left(\alpha_{k}=2\right)$

Fig 1. Shape and dimension of test specimens.

2 種類である。な掞中, 小型平滑試験片の応力集中係 数は $\alpha_{k}=1.002$ 以下となっている. 段付試験片にて
は, 段付部直径を $D, d$, 隅肉半径を $r$ とした場合, 形状係数 $\alpha_{k}=2$ となるようと Peterson の図表より $D / d=1.05, \quad r / d=0.032$ と選び試歌片形状寸法を求 めた。各種試験片は同一粗材より採取し, 中型, 小型 の試験片は, 表面が大型試験片の外周に接する位置よ り採取した。粗材断面のかたさ分布は一様であり,

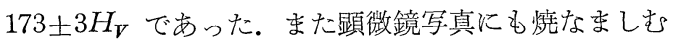
らは見られず, 各種試跧片は寸法形状を除いて同一条 件とみなしてよい. 各種試験片は所定の寸法に機械仕 上の後 Table II に示すように小型, 中型試験片は真 空焼なまし, 大型試験片はアルゴンガス中にて焼なま しを行なった。試験片はすべて表面の薄い酸化膜を除 くため過塩素酸と無水酢酸を 1：4の割合で混合した 電解研摩液で軽く電解研摩を施して試験に供した。

\section{$2 \cdot 2$ 実験 条 件}

小, 中型材は片持回転曲げ疲労試験機 $(20 \mathrm{~kg} \cdot \mathrm{m}$ $1400 \mathrm{rpm}$ )大型忉は大型均一回転曲 $け ゙$ 疲労試験機 (7.8 tm 400〜500 rpm）飞て疲労試験を行なった。各種試 験片の $S-N$ 曲線を Fig. 2 飞示す. 明らかに試験片 寸法により疲労強度が相当相違していることがわかる. な杼，図中大型材については大内田による寸法効果の 研究を参照して小型, 中型材の $S-N$ 曲線上り推定し たものである。

X線回折写真撮影条件を Table III に示すように, $\mathrm{CoK} \alpha$ 線による $\mathrm{Fe}$ の (310) 面回折である. 半価幅 


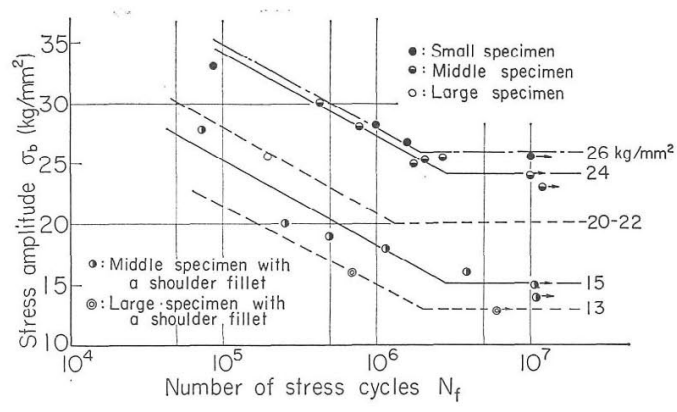

Fig. 2. S-N curve.

Table III. The exposure condition of X-ray back reflection camera.

\begin{tabular}{l|c|c}
\hline & $\begin{array}{l}\text { For half-value } \\
\text { breadth measurement }\end{array}$ & $\begin{array}{l}\text { For powder } \\
\text { photograph }\end{array}$ \\
\hline Characteristic X-ray & CoK $\alpha$ & CoK $\alpha$ \\
Measuring area (mm $\phi)$ & 1 & 1 \\
Tube voltage (kV) & 20 & 20 \\
Tube current (mA) & 5 & 5 \\
Filter & Fe & Fe \\
Film & Fuji 200 Type & Fuji 400 Type \\
Exposure time & 40 min & $2.00 \mathrm{hr}$ \\
\hline
\end{tabular}

測定のためには試料表面に垂直入射X線のフィルム摇 動写真をとり，ミクロフォトメータ（理学電機製 MP -3）にて黑化度曲線字求めた。フィルムの送りに対す るチャート紙の送りは10倍に拡大乙てある。半価愊と しては積分愊 $b$ をとり, 試料の処女状態に和ける半価 愊 Bとの比をもって半価幅変化とした。

X線残留応力測定は， CrK $\alpha$ 線による Fe の (211) 面回折であり，測定条件を Table IV に示す。

\section{3 実験結果と検討}

\section{$3 \cdot 1$ 静止写真による疲労限度の推定}

焼なま乙処女材の静止写真を, Fig. 3 (a) に示す。
Table IV. Measuring apparatus, method and condition of stress analyser with G. M. counter tube.

\begin{tabular}{|c|c|}
\hline Measuring apparatus & $\begin{array}{l}\text { Parallel beam type X-ray } \\
\text { stress analyser with GM } \\
\text { counter tube }\end{array}$ \\
\hline Characteristic $\mathrm{X}$-ray & $\mathrm{Cr} K \alpha$ radiation \\
\hline Measuring method & $\begin{array}{l}\operatorname{Sin}^{2} \phi \text { method }\left(=0^{\circ}, 15^{\circ},\right. \\
\left.30^{\circ}, 45^{\circ}\right)\end{array}$ \\
\hline Measuring area $\left(\mathrm{mm}^{2}\right)$ & $2 \times 2$ \\
\hline Tube voltage $(\mathrm{kV})$ & 20 \\
\hline Tube current (mA) & 5 \\
\hline Count range of ratemeter (cps) & 200 \\
\hline Time constant of ratemeter (sec) & 8 \\
\hline Diffusion angle of slit $\left(^{\circ}\right)$ & 0.17 \\
\hline Goniometer speed $(\% / \mathrm{min})$ & 1 \\
\hline Recording paper speed $(\mathrm{mm} / \mathrm{min})$ & 10 \\
\hline $\begin{array}{l}\text { Measuring method of peak } \\
\text { position of diffraction intensity } \\
\text { curve }\end{array}$ & Half-value breadth method \\
\hline
\end{tabular}

すべての試験片処女材の静止写真はこのように回折は え点は鮮明であり, 回折環上に一様に並んでいる。

$3 \cdot 1 \cdot 1$ 平滑材の場合 疲労限度の応力振幅にて は $10^{7}$ 回繰返乙後も回折はん点のぼけはほとんどなく, 処女材の回折はん点と同じである。この例を Fig. 3

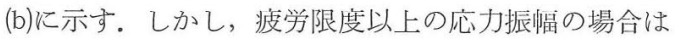
Fig. 3 (c) の例に示すように, 回折はん点はぼけて, 湾とえど連続環を形成するに至り破断する。これは疲 労限度以上の応力振幅では, たとえ降伏点以下の応力 振愊であっても微視的には塑性変形が起こり，進展し， き裂が発生することによると考学られる。疲労限度以 下の応力振幅にては微視的塑性変形も生じないため回 折はん点には変化をきたさないものと思われる。Fig. 3 (b)，(c)に示したと同様の事実は平滑材の寸法をとわ ず認められた。したがって, 平滑材の場合に静止写真
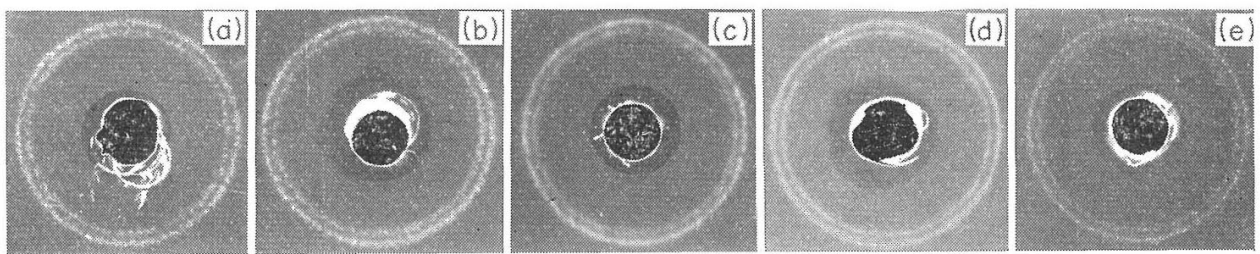

(a) Unnotched specimen of middle size $N=0$

(b) Unnotched specimen of middle size $\sigma_{b}=24 \mathrm{~kg} / \mathrm{mm}^{2} N=10^{7}$ cycles

(c) Unnotched specimen of middle size $\sigma_{b}=25.5 \mathrm{~kg} / \mathrm{mm}^{2} N=3.0 \times 106$ cycles

(d) At the toe of fillet of the large size specimen with a fillet $\sigma_{b}=13 \mathrm{~kg} / \mathrm{mm}^{2} N=1 \times 106$ cycles $\left(\sigma_{w}=13 \mathrm{~kg} / \mathrm{mm}^{2}\right)$

(e) At the end of large section of the large size specimen with a fillet $\sigma_{b}=13 \mathrm{~kg} / \mathrm{mm}^{2} N=1 X$ 106 cycles $\left(\sigma_{w}=13 \mathrm{~kg} / \mathrm{mm}^{2}\right)$

Fig. 3. X-ray diffraction patterns. 
による疲労限度の推定が可能であることがわかった。

$3 \cdot 1 \cdot 2$ 段付材の場合 Fig. 3 (d) は，大型段付 材の疲労限度の応力 $\left(\sigma_{b}=13 \mathrm{~kg} / \mathrm{mm}^{2}\right)$ にて $1 \times 10^{6}$ 回 後の回折写真である。明らかに回折はん点はぼけてお り，ほとんど連続環を形成している。これに対しFig. 3 (e)は，参考のために同じ試験片の段の上に和ける回 折写真を示した。段の上では回折はん点はまだ鮮明で あることがわかる、しかし，この試験片は $\sigma_{b}=13 \mathrm{~kg} /$ $\mathrm{mm}^{2}$ の応力振幅にては $10^{7}$ 回以上の繰返しに耐党, $10^{7}$ 回後に和ける段付底の回折写真は Fig. 3 (d) と同 じであり，回折はん点のぼけの進行はみられなかった。 この事実は中型段付材に沶いても確かめられた。した がって, 段付材では疲労限度あるいはその直下の応力 振幅の繰返しによりX線回折はん点はぼけを生じて円 周方向に広がるが，試験片は破断に未では至らないこ とがわかった：これは平滑材と異なる点である。

X線回折はん点にぼけを生ずるにもかかわらず，段 付試験片では疲労破断にまでは至らないことの原因を 考えてみる.

(a) X線回折はん点にぼけを生ずるための条件，換 言すれば試験片表面に塑性変形が生ずる条件：(b) 疲 労き裂が発生する条件：この(a)，(b)の 2 条件を考学れ ば，平滑材では(a)の条件を満たす場合はほとんど(b)の 条件を満たす。ところが段付材の場合は，(a)の条件が 満たされても必ずしも(b)の条件が満たされない場合が ある.これは試験片に加わる応力の応力こう配の差に 起因するものと推察できよう。この機構についてはさ らに詳しく検討する予定である.

\section{$3 \cdot 2$ 半価幅, 残留応力による疲労の検出（寸法の 相違による比較}

（1）小型試験片の応力繰返しに伴う残留応力变化を Fig. 4 に示す。娔なまし材であるため初期残留応力 は 0 であるが，応力繰返しに伴って圧縮残留応力が生 じ，ある繰返し数にてピークを生じた後減少する傾向 にある. これは平, 本田らの研究と一致する. その変 化の傾向は, 高応力振幅ほど早期に，そしてやや高い 圧縮残留応力が生ずる.

(2) 同一応力振幅 $\left(\sigma_{b}=25.5 \mathrm{~kg} / \mathrm{mm}^{2}\right)$ に打いて,
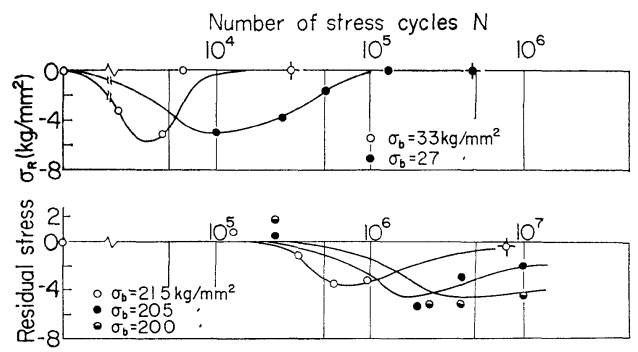

Fig. 4. Change in residual stress in unnotched specimens of small size.

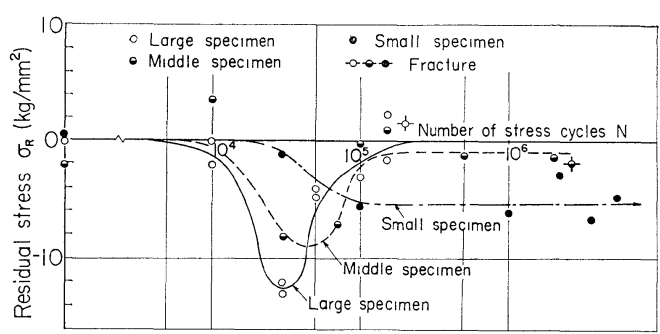

(Unnotched specimen, $\sigma_{b}=255 \mathrm{~kg} / \mathrm{mm}^{2}$ )

Fig. 5. Change in residual stress under the same applied stress in the case of different sizes.

大型 $\left(100^{\phi}\right)$ 中型 $\left(20^{\phi}\right)$ 扎よび小型 $\left(8^{\phi}\right)$ の残留応 力変化を比較したものが Fig. 5 である.すべての試 験片に执いて応力繰返しに伴って压縮の残留応力が生 じ，ある繰返し数にてピークを生じ，やがて減少する。 この傾向は平, 本田らの結果と同じである。乙かし, 大型寸法になるに従い早期に圧縮残留応力のピークが 生じ，しかもその值が比較的大きいことは注目すべき と考学られる。すなわち, 大型試験片の表面残留応力 の変化は小型試験片の, より高応力振幅に相当する変 化を示す.一方, 大型材は小型材に比べて疲労寿命が 少ないから, 残留応力変化は, 試験片に実際に生ずる 疲労被害に対応しているといえる.

(3) 同じく同一応力振幅 $\left(\sigma_{b}=25.5 \mathrm{~kg} / \mathrm{mm}^{2}\right)$ にお ける大, 中, 小型試験片の半価幅変化を比較したもの が Fig. 6 である。

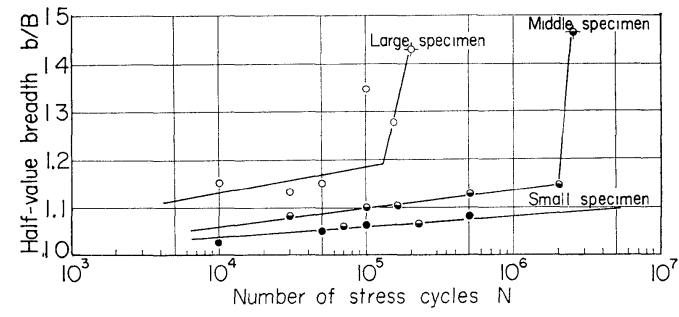

(Unnotched specimen, $\sigma_{b}=255 \mathrm{~kg} / \mathrm{mm}^{2}$ )

Fig. 6. Change in half-value breadth under the same applied stress in the case of different sizes.

いずれも単調に増加し, その増加の割合は繰返し数 を対数目盛に表わせば直線的になる。これも平, 本田 らの結果と一致するものである.

さて, Fig. 6 に示されるよらに大, 中, 小型材の 順に半価幅の増加割合が大さい。すなわち, 半価幅の 変化は, 負荷される応力に依存するのではなく, 試験 片の寿命に依存するよらである，換言すれば，X線に て検出される試験片の表面の受ける疲労被害の程度は, 試験片の寿命に密接に関係しているようである.そこ で各種寸法の試験片に拈ける半価幅変化を繰返し数比 


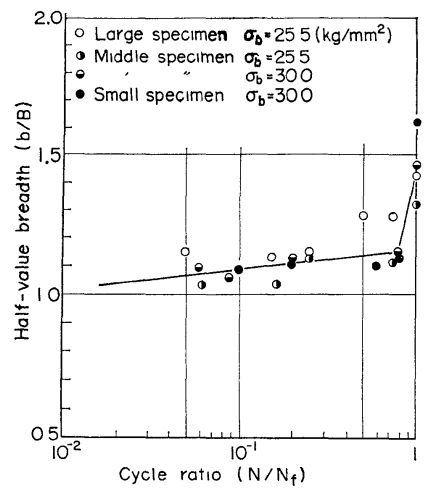

F1g. 7. Change in half-value breadth.

$N / N_{f}\left(N_{f}\right.$; 破断繰返し数)を横軸にとって表わした のが Fig. 7 である。执拈よそ一本の単調増加直線に まとまるようである。

これより, 寸法の相違によらず半価幅は試験片の受 ける実際の疲労被害の程度に依存して変化することが わかった. すなわら, 疲労強度に及洔す寸法効果の影 響がある場合にも, 暁なむし炭素鋼に和いては疲学破 壊の予知が可能である. Fig. 5，6 に示される事実は 寸法効果の機構を検討する上に, 試験片表面の受ける 被害が重要なことを示すものであろう。この原因とし て，寸法の差異によらず，少なくともX線的に検出さ れらる一定の層の被害が応力こう配の差により強調さ れることが考えられる。

\section{4 結 言}

焼なまし炭素鋼（SF 55）の同一粗材より採取した 平滑試験片 (大型 $100^{\phi}$, 中型 $20^{\phi}$, 小型 $8^{\phi}$ ) および 段付試験片（大型 $80^{\phi}$, 中型 $15.65^{\phi}$ ) に执いてX線的
疲労の検出を試みた結果，次のことがわかった。

（1）粉末写真により, 平滑試験片にては負荷応力振 幅が疲労限度以上か以下かの判定が，寸法のいかんに かかわらずほぼ可能である。段付試験片にては疲労限 度あるいはその直下の応力振幅においても X線回折は ん点はぼけを生ずるため, 粉末写真によって実際の疲 労限度よりもわずかながら小さい応力振幅をもって疲 労限度と判定される。

（2）疲労強度に及ぼす寸法効果の影響がある場合に も X線的には試験片の寿命に依存して, 半価幅, 残留 応力が検出されらることがわかり, 試験片表面のX線 的観察にて疲労検出が可能である.

終わりに本研究を行ならにあたり, 実験上の便宜を はかっていただいた武蔵工大の吉岡氏に感謝します。 また有益なご助言を晹わった当所楠本主任研究員, 実 験に協力された根本, 久保木の両氏に厚くお礼申し上 げホす。

（昭和43年 7 月18日 第 7 回X線材料強度に関するシンポジウムにて 講窝）

\section{参考 文 献}

1）たとえば大内田久, Bulletin of JSME， 15, 587 (1962).

2）たとえば大内田久, 日本材料学会編, “金属の疲労”, p.244 (1964) 丸善

3）たとえば平 修二, 本田和男, 日本機械学会論文集, 26, 167 (1960).

4) Peterson, R.E., Stress Concentration Design Factors (1958) John Wiley, New York.

5）大内田久, 日本機械学会論文集， 28，185 (1962); 日本 機械学会誌, 62, 484 (1960); 64, 505 (1962). 